\title{
Insects in European feed and food chains
}

Veldkamp, T.; Eilenberg, J.

Published in:

Journal of Insects as Food and Feed

DOI:

10.3920/JIFF2018.x006

Publication date:

2018

Document version

Publisher's PDF, also known as Version of record

Citation for published version (APA):

Veldkamp, T., \& Eilenberg, J. (2018). Insects in European feed and food chains. Journal of Insects as Food and Feed, 4(3), 143-145. https://doi.org/10.3920/JIFF2018.x006 


\title{
Insects in European feed and food chains
}

\author{
T. Veldkamp ${ }^{1 *}$ and J. Eilenberg ${ }^{2}$ \\ ${ }^{1}$ Wageningen Livestock Research, Wageningen University E Research, P.O. Box 338, 6700 AH Wageningen, the Netherlands; \\ ${ }^{2}$ University of Copenhagen, Department of Plant and Environmental Sciences, Thorvaldsensvej 40, 1871 Fredriksberg C., \\ Denmark; teun.veldkamp@wur.nl
}

\section{OPEN ACCESS (C) (1) (9) (2)}

EDITORIAL

Insects or insect products are valuable feedstuffs for animal feeds but for further implementation more research is required. Different symposia contribute to sharing the obtained knowledge and in this special issue the activities of the EAAP study commission Insects are highlighted as well as five papers presented during the 2017 annual EAAP meeting in Tallinn, Estonia and one paper presented during the 'Insectinov2 2017' meeting in France. The papers highlight different aspects of the insect chain such as sustainability, insect health, bacterial contamination, nutritional value of insect meal and regulatory system.

\section{Introduction}

From 15 to 18 May 2018 the $2^{\text {nd }}$ International Conference 'Insects to Feed the World' was held in Wuhan, China. The number of delegates participating in this conference was almost 300 from all parts of the globe. This conference and many other events have proven that the sciencebased knowledge as well as innovations and applications of techniques by the industry are increasing rapidly. Based on hits in Web of Science using the term 'edible insects' 90 articles were published in 2017 and this number was more than the 82 articles published in total during the 10 year period from 2005 to 2014 (Van Huis, 2018). Payne et al. (2016) has given a broad overview of the key themes and challenges in the field of insects as food and feed, from a predominantly European perspective. It is of utmost importance to join forces in order to tackle industry challenges that hamper further development of the insect chain.

In 2015, the General Assembly of the United Nations adopted 17 sustainable development goals (SDGs) in order to set the world on a sustainable and resilient route (UnitedNations, 2015). Insect species considered as animal feed all have high levels of protein and moreover amino acid profiles are suitable to be used as feedstuffs (Henry et al., 2015; Makkar et al., 2014; Van Huis and Tomberlin, 2017; Veldkamp and Bosch, 2015) and these can be used as a natural nutrient source for poultry (Józefiak et al., 2016). In this special issue it is described that insects do not only provide excellent opportunities to replace fishmeal and soya bean meal, but may also have important additional benefits such as positive effects on livestock health and welfare with opportunities to reduce antibiotic use in livestock production. This contributes significantly to the SDGs in a lot of aspects. Currently, produced quantities of insect products are in general small. For supply of insects as feed ingredient for livestock further upscaling is required and the special issue focusses on rearing facilities at different scales of production. It is stated that communication between industry groups and researchers is required to promote a fast and effective development of the insect sector. By upscaling, insect rearing farms also increase the risk for detrimental insect diseases entering the insect farm and causing high economic losses to the farmer.

\section{European platforms for knowledge exchange}

In Europe there have been several events in 2017 and new platforms have been established to share knowledge and to start networks to collaborate on all aspects of insects in feed an food chains. The platforms include the annual event in Germany 'Insecta' (http://insecta-conference.com), the 'Insectinov' meetings in France (http://adebiotech. org/ins2/en.ins2.php), the insect producers' umbrella organisation IPIFF (http://www.ipiff.org/) and the EAAP Study Commission Insects (http://www.eaap.org/insectsc/). In the next paragraph the activities and aims of the in 2016 launched EAAP Study Commission Insects are further explained.

\section{EAAP Study Commission Insects}

The Study Commission Insects was launched in 2016 under the umbrella of the European Federation of Animal Sciences (EAAP) because insects as animal species are 
considered now as a (mini)livestock sector (FAO, 2013) and faces also research themes and challenges as other livestock sectors for ruminants, pigs, horse and sheep. The distinction between livestock and mini-livestock is not always clear: mini-livestock implies small animals raised for domestic use or profit (not as pets), especially on a farm. These can be small mammals, amphibians, reptiles or invertebrates, including insects (Paoletti, 2005). The commercial insect sector is relatively new and the sector is faced with many research questions for further innovation of the insect chain. The EAAP Study Commission Insects addresses all questions in the area of biomass as substrate for insect rearing, nutritional requirements of insects, insect production, ethical aspects, processing methods of insect products, feeding value of insects (products) in animal feed, functional properties of insect products in animal feed, market applications, regulatory issues, consumer acceptance, environmental and socio-economic sustainability. The different aspects are clustered in the following themes and are formulated as:

1. Insects in a circular economy. All aspects with respect to reducing wastes, creating/ onverting low grade to high grade protein, upgrading biomass to high quality products, biodiversity, reduction of water usage, land use, life cycle assessment, upscaling of production, insect disease issues, reduction of manpower through automation, selection of suitable insects for specific indications and locations, insect breeding and insect diseases.

2. Potential of insect products for feed, food and nonfood. All aspects regarding novel processing approaches, developing protocols to determine nutrient requirements of insects, digestibility of insect products in animal feed, optimal and natural feeds, improve shelf life and use of components of insects (e.g. chitin) in feed and food applications.

3. Safety, regulatory issues and consumers. This theme includes safe products, quality control, hygiene, HACCP, standardisation of methods and parameters, consumer acceptance and food security.

Besides invited speakers also a call for abstracts will be launched every year for the annual EAAP meeting. At the 2017 meeting in Tallinn, Estonia, there were oral and poster presentations about insects. The next meeting is on Wednesday 29 August 2018 in Dubrovnik, Croatia and the annual meeting in 2019 will be held in Ghent, Belgium. Insect papers will be presented in thematic insect seminars. The insect seminar is included in a comprehensive program including genetics, physiology, welfare and behaviour and nutrition for different livestock sectors. In this way industry and academic community of larger livestock sectors can get acquainted with the insect sector and vice versa to obtain at one location the latest knowledge in the area of insects but also in the area of larger livestock sectors. Abstracts of the annual meeting are available after the annual meeting on the website http://www.eaap.org. The Study Commission Insects has its own informative website http://www.eaap. org/insectsc/ with the latest publications, activities and news about the insect sector.

\section{Review and research publications in this issue}

In this special issue we have included papers based on presentations at the EAAP Annual Meeting, Tallinn 2017 and of Insectinov2, 2017. The publications include reviews of the current status on different aspects in the insect industry such as insects as feed and the sustainable development goals (Dicke, 2018), coordination of European activities to diagnose and manage insect diseases in production facilities (Eilenberg et al., 2018) and the impact of the insect regulatory system on the insect marketing system worldwide (Lahteenmaki-Uutela et al., 2018). It is essential to bridge gaps between academia, industry and traditional knowledge (Berggren et al., 2018). In several European countries, upscaling of existing production and initiation of new production facilities is ongoing. Large national projects have been undertaken, involving companies and academia in a joint effort. Besides these overviews also two research publications are included in this issue. One paper is about Campylobacter contamination level in houseflies after exposure to materials containing Campylobacter (Jensen and Hald, 2018). This paper illustrates that there is a strong potential for contamination of houseflies in a natural farm setting so be aware of high hygienic measurements to avoid contaminations. Another paper presents data on protein composition and digestibility of black soldier fly (Hermetia illucens) larvae in broiler chickens according to recent nitrogen-protein conversion ratio (Nery et al., 2018).

\section{Conclusions}

Research and innovation collaboration on precompetitive issues and knowledge sharing in existing or new platforms will benefit the fast development of the insect sector and will help to face challenges occurring along upscaling of insect production. Also, authorities involved with food safety are essential players to assist getting insects established as mini-husbandry, in Europe and elsewhere.

\section{References}

Berggren, A., Jansson, A. and Low, M., 2018. Using current systems to inform rearing facility design in the insect-as-food industry. Journal of Insects as Food and Feed 4: 167-170.

Dicke, M., 2018. Insects as feed and the sustainable development goals. Journal of Insects as Food and Feed 4: 147-156.

Eilenberg, J., Van Oers, M.M., Van Loon, J.J.A., Jensen, A.B., Lecocq, A., Maciel-Vergara, G., Santacoloma, L.P.A. and Hesketh, H., 2018. Towards a coordination of European activities to diagnose and manage insect diseases in production facilities. Journal of Insects as Food and Feed 4: 157-166. 
Food and Agriculture Organisation (FAO), 2013. Edible insects Future prospects for food and feed security. FAO Forestry Paper 171, Rome, Italy.

Henry, M., Gasco, L., Piccolo, G. and Fountoulaki, E., 2015. Review on the use of insects in the diet of farmed fish: past and future. Animal Feed Science and Technology 203: 1-22.

Jensen, A.N. and Hald, B., 2018. Campylobacter contamination level in houseflies after exposure to materials containing Campylobacter. Journal of Insects as Food and Feed 4: 179-185.

Józefiak, D., Józefiak, A., Kierończyk, B., Rawski, M., Świątkiewicz, S., Długosz, J. and Engberg, R.M., 2016. Insects - a natural nutrient source for poultry - a review. Annals of Animal Science 16: 297-313.

Lahteenmaki-Uutela, J.D., Henault-Ethier, L., Marimuthu, S.B., Talibov, S., Allen, R.N., Nemane, V., Vanderberg, G. and Jozefiak, D., 2018. The impact of the insect regulatory system on the insect marketing system. Journal of Insects as Food and Feed 4: 187-198.

Makkar, H.P.S., Tran, G., Heuzé, V. and Ankers, P., 2014. State-ofthe-art on use of insects as animal feed. Animal Feed Science and Technology 197: 1-33.

Nery, J., Gasco, L., Dabbou, S. and Schiavone, A., 2018. Protein composition and digestibility of black soldier fly larvae in broiler chickens revisited according to recent nitrogen-protein conversion ratio. Journal of Insects as Food and Feed 4: 171-177.
Paoletti, M., 2005. Ecological implication of minilivestock. role of rodents, frogs, snails, and insects for sustainable development. Science Publishers Inc., Boca Raton, FL, USA.

Payne, C.L.R., Dobermann, D., Forkes, A., House, J., Josephs, J., McBride, A., Müller, A., Quilliam, R.S. and Soares, S., 2016. Insects as food and feed: European perspectives on recent research and future priorities. Journal of Insects as Food and Feed 2: 269-276.

United Nations, 2015. General assembly, resolution 70/1: transforming our world: the 2030 agenda for sustainable development. UN, New York, NY, USA.

Van Huis, A., 2018. Insects for food, feed and health: a global perspective. Journal of Insects as Food and Feed 4(Suppl1): S3. Available at: https://doi.org/10.3920/JIFF2018.S1.

Van Huis, A. and Tomberlin, J.K., 2017. Future prospects of insects as food and feed. In: Van Huis, A. and Tomberlin, J.K. (eds.) Insects as food and feed: from production to consumption. Wageningen Academic Publishers, Wageningen, the Netherlands, pp. 430-445. Veldkamp, T. and Bosch, G., 2015. Insects: a protein rich feed ingredient in pig and poultry diets. Animal Frontiers 5: 45-50. 
